\title{
The Transformation of Islamic Education in a Disruptive Era: is it A Necessity?
}

\author{
Desi Puspitasari ${ }^{1}$, Bustanul Yuliani ${ }^{2}$, Moh. Khoridatul Huda ${ }^{3}$ \\ IAIN Ponorogo ${ }^{1}$, IAIN Ponorogo ${ }^{2}$, University of Warwick, $\mathrm{UK}^{3}$ \\ \{desipus@iainponorogo.ac.id ${ }^{1}$, bustanulyulia@iainponorogo.ac.id², Moh.Huda@warwick.ac.uk³
}

\begin{abstract}
Disruption becomes a global development that happens within the age 4.0 era. It is full of changes, which demands a highly competitive environment, as well as in education. It is said that Islamic education, which includes Islamic boarding school and madrasa plays an important role. It is because Islamic education is considered as a noble position. It includes a group of ideas and tenets bearing on human nature, creed, intellect, and attitude, alongside religious and physical values. Through Islamic education, people are educated and polite, following an encompassing technique that involves those aspects. This paper discussed the portrait of Islamic education in Indonesia. It explored the Islamic education origin. It also determined its necessity in the era of revolution 4.0. The results show that Islamic education needs to transform to some extent to face the disruption era, and making disruption because of the future and chance to pioneer and improve the standard of Islamic education.
\end{abstract}

Keywords: Islamic education; transformation; disruptive era

\section{Introduction}

History proves that Islam entered Indonesia in the 7 th century $\mathrm{AD} / 1 \mathrm{H}$. But it only expanded in the 13th century AD. The expansion of Islam marked the establishment of the oldest Islamic kingdoms in Indonesia, such as Perlak and Samudra Pasai in Aceh in 1292 and 1297. Through the trading centers on the coast of North Sumatra and the arteries of trade in Malacca, Islam then spread to the island of Java and beyond to eastern Indonesia. According to Daulay, Islamic education institutions in Indonesia include Islamic boarding school, schools, madrasas, official schools, and Islamic higher education. At the same time, the learning methods vary according to the level of education.

Changes in the form and content of Islamic education in Indonesia in the modern era cannot be separated from the demands of the times. Some researchers often write research on the development of modern Islam in Indonesia, but the orientation is only in the coverage of traditions from urban areas which are quite crucial to explain the Islamic tradition in Indonesia.

Karel interested in researching the development of Islam do in working on his dissertation in 1970. Karel run into a lot of trouble since from the Netherlands to submit a proposal containing a research project on the Islamic world of the twentieth century which is experiencing a revival, spearheaded by reformist groups, such as Jamaluddin al-Afghani, Muh. 
Abduh, Rsyid Ridla, et al. The results of the reformist group's thoughts, among others, were channelled through the interpretation of the Koran.

In the end, Karel was interested in doing his research on hut object boarding schools a culture of Islamic Education in Indonesia, for two reasons. First, because life in an Islamic boarding school, if observed and experienced for a longer period, will provide a more interesting experience of life in a typical Islamic environment. Second, it is a scientific cause. Karel believes that this aspect of life (in the world of Islamic boarding school) has not been described in modern studies of Islam in Indonesia.

Karel's research on this Islamic boarding school provides scientific contributions. By paying attention to and experiencing life in an Islamic boarding school for a longer time, it will provide a more interesting experience of life in a typical Islamic environment; and Karel can describe aspects of life in the Islamic boarding school world in modern studies of Islam in Indonesia, even though Karel is from non-Muslims. Islamic boarding school is part of Islamic education. A. Tafsir et al. argues that the responsibility of Islamic education is oriented towards social life. Also, it always provides good teachings for educated people, and vice versa always avoids negative things. Daulay conveyed, although there have been dynamics in the world of Islamic boarding school, Islamic boarding school are in their original function, namely as an educational institution to produce Islamic religious experts.

In terms of terminology, it can be explained that Islamic boarding school education, in terms of form and system, originates from India. Before the process of spreading Islam in Indonesia, this system was generally used for Hindu religious education and teaching. After Islam entered and spread in Indonesia, the system was then adopted by Islam. The term Islamic boarding school itself is like the term reciting, langgar, or surau in Minangkabau, Rangkang in Aceh does not come from an Arabic term, but rather from India.

Islamic boarding school in the challenges of various times has shown its quality. As the oldest educational institution in Indonesia, Islamic boarding school are always required to perform optimally, and this has been proven so that it does not rule out that Islamic boarding school are the ideal educational institutions in the national education system. Because even though there are various weaknesses in it, at least the potentials needed to meet the demands of an ideal typology of educational institutions have been fulfilled. So that without the existence of Islamic boarding schools, Islamic education institutions in Indonesia will not develop, because the Islamic boarding school system provides color in Islamic education which continues to develop with innovations that are tailored to the needs of society and the demands of the times.

Based on the explanation, an Islamic boarding school have a big share of education in Indonesia. Hasbullah also argued that the Islamic boarding school, which at first took place, turned out to be quite instrumental and colored the history of Islamic education in Indonesia a lot. Even Islamic boarding school have produced many famous figures. However, as time went by, the competition got tighter. There are inevitable demands of the times, especially when we enter the era of revolution 4.0. Therefore, the researcher formulated several problem formulations. First, it describes the portrait of Islamic education in Indonesia and dualism education. It also defines the origin of the Islamic boarding school system. Next, it finds out the renewal of Islamic education in Indonesia as an aspect of Islamic renewal at the beginning of the $20^{\text {th }}$ century. At last, it portrays the Islamic education in the era of revolution 4.0.

This research is important to study, considering it has a role in the formation of the golden generation in Indonesia. It is done to determine the extent of the readiness of Islamic education to welcome the revolution that is in sight. 
This research employed the library research method using written materials such as manuscripts, books, magazines, newspapers and other documents. It employed Karel's book as the reference and the other related research. A literature study is a data collection method that is directed at finding data and information through documents, both written documents, photographs, images, and electronic documents that can support the writing process. Research results will also be more credible if they are supported by existing photographs or academic and artistic papers.

There are four steps of library research, namely: first, preparing equipment, tools in library research are only pencils or pens and notepaper. Second, compiling a working bibliography. A working bibliography is a record of the main source material that will be used for research purposes. Most of the bibliographic sources come from library collections that are on or not on display. Third, set the time. In terms of managing this time, depending on the person who takes advantage of the available time, it could be planning how many hours a day, one month, it's up to the person concerned to use the time. Fourth, reading and making research notes. It means that what is needed in the research can be noted.

\section{Islamic Education in Indonesia}

\subsection{Islamic Boarding School as an Islamic Education Institution}

Islamic boarding schools in Indonesia have a very big role, both for the progress of Islam itself and for the Indonesian nation as a whole. Based on existing records, religious education activities in the archipelago have been started since 1596. These religious activities are later known as Islamic boarding schools. Even in the notes of Howard M. Federspiel - one of the researchers of Islam in Indonesia, by the twelfth-century study centers in Aceh and Palembang (Sumatra), in East Java and Gowa (Sulawesi) had produced important writings and has attracted students to study.

Now, during the National Education system, which is always changing in a short period, the appreciation of the Indonesian Islamic community for Islamic boarding schools is getting bigger and bigger. The Islamic boarding school, which was originally a Rural Based Institute, has developed into an urban education institution. Look at the emergence of some urban Islamic boarding schools such as in Jakarta, Bandung, Medan, Pekanbaru, Yogyakarta, Malang, Semarang, Ujung Pandang, or sub-urban Jakarta such as Parung, Cilangkap. Or for example, the Islamic boarding school that emerged in the 1980s such as the Darun Najah, Cianjur, and Ashidiqiyah Islamic boarding school in Jakarta; Islamic boarding school Nurul Hakim, al-Kautsar, Darul Arafah in Medan, Mustafawiyyah Purba Baru in Mandiiling-Natal and there are now around it, Darul Hadits Hutabaringin, Darul Ikhlas in Dalan-lidang, and Islamic boarding school Muara Mais.

Islamic boarding schools that provide an understanding of religion play a role in producing religious experts or clergy. In the Regulation of the Minister of Religion Number 13 of 2014 concerning Islamic Religious Education that the implementation of Islamic boarding school education as part of Islamic religious education aims to: (a) instil in students to have faith and devotion to Allah SWT., (B) develop abilities, knowledge, attitudes and the skills of students to become experts in Islamic religious studies (mutafaqqih fi al-din), and (c) develop personal morals for students who have individual and social piety by upholding the spirit of sincerity, simplicity, independence, brotherhood among Muslims (ukhuwah Islamiyah), humble (tawadhu '), tolerant (tasamuh), balance (tawazun), moderate (tawasuth), exemplary (uswah), 
Islamic boarding school as an educational institution that grows and develops amid society at the same time combines three very important elements of education, namely: worship in instilling faith, tabligh for the spread of knowledge and charity to demonstrate community activities in everyday life. KH Ali Maksum provides data to determine the various patterns of Islamic boarding school, as seen in the following table:

Table 1. The various patterns of Islamic boarding school

\begin{tabular}{|c|c|c|c|}
\hline No. & Medium & $\begin{array}{l}\text { Teaching } \\
\text { Method }\end{array}$ & Information \\
\hline 1. & $\begin{array}{l}\text { a. Mosque } \\
\text { b. Kyai's house }\end{array}$ & $\begin{array}{l}\text { Weton and } \\
\text { sorogan }\end{array}$ & $\begin{array}{l}\text { This Islamic boarding school is still simple where } \\
\text { the kyai uses his mosque or house for teaching. In } \\
\text { this pattern, the students only come from the area } \\
\text { around the Islamic boarding school, but they have } \\
\text { studied religion continuously and systematically. }\end{array}$ \\
\hline 2. & $\begin{array}{l}\text { a. Mosque } \\
\text { b. Kyai's house } \\
\text { c. Cottage }\end{array}$ & $\begin{array}{l}\text { Weton and } \\
\text { sorogan }\end{array}$ & $\begin{array}{l}\text { In this case, the Islamic boarding school already } \\
\text { has a pondok or dormitory provided for students } \\
\text { who come from other areas. }\end{array}$ \\
\hline 3. & $\begin{array}{l}\text { a. Mosque } \\
\text { b. Kyai's house } \\
\text { c. Cottage } \\
\text { d. Madrasah }\end{array}$ & $\begin{array}{l}\text { Weton and } \\
\text { classical }\end{array}$ & $\begin{array}{l}\text { Islamic boarding schools that provide educational } \\
\text { facilities in madrasah with a class system. } \\
\text { Sometimes madrasa students with a class system. } \\
\text { Sometimes the madrasa students come from the } \\
\text { Islamic boarding school area itself. Besides, there } \\
\text { are madrasas; the sorogan system is still strictly } \\
\text { implemented at the time determined by the kyai or } \\
\text { the cottage caretakers. }\end{array}$ \\
\hline 4. & $\begin{array}{l}\text { a. Mosque } \\
\text { b. Kyai's house } \\
\text { c. Cottage } \\
\text { d. Madrasah } \\
\text { e. A place of } \\
\text { skill }\end{array}$ & $\begin{array}{l}\text { classical, } \\
\text { sorogan and } \\
\text { skills training }\end{array}$ & $\begin{array}{l}\text { Besides doing the pattern (3), students are also } \\
\text { allowed to train themselves in several skills, such } \\
\text { as livestock, handicrafts, cooperative shops, rice } \\
\text { fields and fields. }\end{array}$ \\
\hline 5. & $\begin{array}{l}\text { a. Mosque } \\
\text { b. Kyai's house } \\
\text { c. Cottage } \\
\text { d. Madrasah } \\
\text { e. A place of } \\
\text { skill } \\
\text { f. University } \\
\text { g. Meeting hall } \\
\text { h. Sports } \\
\text { venues } \\
\text { i. Public school }\end{array}$ & $\begin{array}{l}\text { classical, } \\
\text { sorogan } \\
\text { certified } \\
\text { schools and } \\
\text { colleges }\end{array}$ & $\begin{array}{l}\text { These Islamic boarding schools are often called } \\
\text { modern Islamic boarding school, have supporting } \\
\text { facilities, and there are also public schools or } \\
\text { madrasas for the surrounding community. In } \\
\text { general, this model of Islamic boarding school uses } \\
\text { an accredited training phase through a diploma. }\end{array}$ \\
\hline
\end{tabular}

Studies on the development of modern Islam in Indonesia are often written from the perspective or with the main background of the modernist movement. For example, Clifforo Geertz provides an overview of the Islamic boarding school (and the large organization that manages the institution: Nahdatul Ulama) from the perception of the respondent who is most familiar with him, namely Muhammadiyah people from the city.

Dr BJ Boland, in his book The Struggle of Islam in Modern Indonesia (The Haque 1971), pays special attention to the new institutions in Islam in Indonesia: traditions that are simply continued in the countryside are not given careful attention. 


\subsection{Dualism Education}

According to Karel, the origin of dualism education (a type of amalgamation between Islamic education and general education) in the world of Islamic education in Indonesia began with its emergence since the Dutch colonial administration. The type of education that exists in Indonesia is still ancient by using the existing Islamic education types. The starting point for the development of a general education system was the emergence of a zending school created by the Dutch colonial government with Christian-style education. As with Islamic education at that time, education in zending schools was initially only studying religious issues which were learned through the Bible scriptures, which were translated into Malay. During its development, this zending school finally entered public school education.

Zending education is education that is closer to general education in Indonesia because, in its teaching practice that already uses Latin writing and Malay language, it is not like Islamic education which in practice uses Arabic writing, zending is easier to develop its education system towards general education than Islamic education which was considered difficult to accept renewal, zending received support from the government at that time. In contrast, Islamic education did not receive support from the government. There was a change in the zending education system to general education at the decree of the Dutch ministry as a school for prospective governor employees. Hence, it is easy to understand that the zending method is indeed more realistic to general education than Islamic education.

Islamic schools have since taken their path, independent of the governorship, sticking to their traditions, but are also open to changes in those traditions. Thus, from the beginning of this century, Islamic education began to develop its education model which was different and separate from the Dutch education system, as well as the education system implemented by the Indonesian Ministry of Education and Culture. The Islamic education system, as it is today, will gradually adjust itself and enter the general education system.

\subsection{The Situation of Islamic Education at the Beginning of the $20^{\text {th }}$ Century}

According to Karel, it was the type of Islamic boarding school that represented Islamic education at that time and the role of colonial education. Islamic boarding school education in the late $19^{\text {th }}$ to early $20^{\text {th }}$ centuries is broadly divided into two types of education models or levels, as follows:

\section{a) Islamic boarding schools teaching the Koran (the simplest level of Islamic education)}

The teaching material uses the Al-Qur'an as the center of study, so it is called recitation of the Qur'an, including lessons to read the Al-Qur'an, surah Al-Fatihah as a beginning and followed by short letters to juz amma (juz 30 in the Qur'an). Besides that, it also teaches about ubudiyah (the practice of worship) concerning prayer procedures and procedures for wudlu as well as some daily prayers.

The teaching method used at this level of teaching is studying Arabic letters and memorizing texts in the Qur'an. This education is usually given individually at the house of a teacher / ustadz, in violation, prayer room or mosque or at the house of the parents of students, usually among parents who have important or noble positions. In general, students at this phase of Islamic boarding school are children aged 6-10 years; the strategy used by $u s t a d z$ in teaching is using the sorogan method, which takes approximately $1 / 2$ hours of an individual. 
In this individual-patterned education system, there is often a large difference in learning time between clever students and less intelligent students, namely with different completeness times for each student. Teachers in this education phase are mostly male teachers, but some female teachers prioritize teaching girls or boys who have not reached adulthood. After a student has finished reading the Koran, a tammatan or khataman ceremony is usually held which is complemented by the circumcision ceremony for a boy as the initialization of puberty in Islam.

\section{b) Islamic Boarding Schools Where the Recitation Uses the Book (Advanced Islamic Education Level)}

In this second level, according to Karel, it is very different from the first level of education, it is more organized. It can be seen from three existing aspects: The students of this study of the book generally enter a dormitory within an educational institution which is often referred to as an Islamic boarding school; The subjects given cover more subjects than the Koran recitation. Usually begins with language education, and Education is given not only individually but also in groups.

The first stage in the study of books is to learn about Arabic all students learn Arabic, which is arranged in short descriptions in the form of rhymes - taught by an auxiliary teacher or student from an advanced level who gets the teaching trust of a Kyai. What is also taught by the $u s t a d z$ from among the santri who are senior and have a mandate from the Kyai. However, in the past, the timeframe in the first stage was quite long, even reaching six years, this was due to the lack of supporting facilities and lack of discipline in teaching.

After completing the Arabic grammar stage, then a santri begins religious lessons such as fiqh, ushuluddin, tauhid, and the interpretation of the Qur'an. The teaching method is not only given individually but uses the halaqah method. In this method, the teacher reads the text line by line, translating if deemed necessary an explanation that is heard by several students at once.

The form of Islamic boarding school settlements consisting of Kyai houses, places of worships are also used for teaching (called mosques if they are used for Friday prayers or surau and breaking if they are not used for Friday prayers, as well as a residential area for students called huts that are made themselves by the santri from bamboo or wood. In a small Islamic boarding school, it usually accommodates several tens to hundreds of santri while in large Islamic boarding school, it is usually able to accommodate thousands of students.

The social characteristics of life in the Islamic boarding school world are not only a place for students to study but a place that applies the values of Islamic teachings or a place of worship which is full of self-approach to Allah. Like the implementation of the five daily prayers, the holy book recitations that are sung beautifully according to the rules of recitation which cannot be found in other places. And another social characteristic is the existence of a bond between a santri and a Kyai, which is a boundless obedience relationship that the Kyai is the most central person in the Islamic boarding school. However, in daily life in the Islamic boarding school, almost all of its activities are regulated by the students themselves. Kyai only teaches by reading books, becoming priests and preachers, being role models, advising, and treating.

According to him, the origin of the Islamic boarding school system comes from India, which was first entered before the process of spreading Islam in Indonesia, which the Javanese have used this system for learning Hinduism. After Islam entered and spread in Java, the system was later adopted by Islam. According to him, this can be seen from the terms used to 
describe places or matters relating to Islamic boarding school education which are taken from Indian and not Arabic. Such as the terms of the Koran, pondok, langgar etc. Besides, according to him, the form of the Islamic boarding school education system like in Indonesia was not detected in the area of origin of Islam, namely in Mecca. Even this education system is also attached to Hindu elements, among others: The entire education system is religious, teachers do not get a salary.

\subsection{Renewal of Islamic Education in Indonesia as One Aspect of Islamic Transformation at the Beginning of the $21^{\text {st }}$ Century}

The emergence of various movements for reforming Islamic education in Indonesia at the beginning of the $21^{\text {st }}$ century which was based on one of four main factors: Since 1900 in several places the desire of Islamic thinkers has emerged to return to the purity of Islamic teachings that are oriented towards the teachings of the Qur'an ' an and Sunnah; The high sense of nationalism in the Indonesian people facing Dutch colonialism; The strong efforts of Muslims in Indonesia to strengthen their organizations in the social and economic fields; As well as the emergence of an awareness of Muslims towards renewal in the field of Islamic education which is considered backwards in its educational methods.

This period is a period of debate between Islamic Salafi and Islamic modernists as a process of disputing changes in the Islamic education system, which in the end the views of Muslims fluctuate with changes outside the system or cultural system by wanting to adopt the Western system in the context of the method and not the content and purpose of education. In this case, the santri are not only limited to the definition of people studying in traditional Islamic boarding school but also students of madrasas or other educational institutions that follow the concept of the Department of Religion. Indeed, some also reject the term santri only for traditional Islamic boarding school and not for modern Islamic school students. However, this assumption was rejected by some IAIN students and PGA students. Because these students and students still live in an environment that is separated from the environment of public school students, the term santri is still acceptable even though it is reserved (reserve).

The typical Islamic boarding school education can instil strong religious emotions in students. Dr A. Mukti Ali, in one of his writings quoted by Karel, stated this as follows: "Islamic boarding school education is good, but there is also a lack. The good thing is that the religious teachings that are carried out can educate religious feelings, instil a sense of religion. Reciting with songs and rhythms that are certainly longing for the heart to the far and unseen, to Allah Almighty, who makes all nature exciting. The religious knowledge gained by the Koran is not deep. People do not know the meaning that is read in a song that longs for the soul. But the feeling of religion becomes deep, the soul is educated in the paths of being holy and pure, and the religion that has been embedded in the soul since childhood remains a lamp for life. Islamic boarding schools are religious, instructional establishment that have their singularity and are completely different from other educational institutions in implementing a religious education and teaching system.

In the $21^{\text {st }}$ century, Islamic boarding school was indeed a separate world that had its customs and norms because, at that time, there had not been any clear competition. This competition arose when schools were founded. The Islamic boarding school system is a cure for all diseases, as well as being a cheap tool in the implementation of literacy because Islamic boarding school teachers are not paid or charge school fees. What is appreciated by the Islamic boarding school is that they are democratic, students receive the same treatment, for example working in the fields to reap rice, praying for fellow Muslims at the grave, this is a strong 
bond of brotherhood. Many beautiful words are praising Islamic boarding school as institutions and strongholds of Islam, but Islamic boarding school and madrasas are getting less and less valued socially.

\subsection{Islamic Education in the Revolution Era 4.0}

Education 4.0 is a general term used by educational theorists to describe the various ways to integrate cyber technology both physically and indirectly into learning. The problem of Muslims is a crisis of contemporary thought. Society has a multidimensional crisis concerning the political, social, economic, psychological and educational domains. Anealka Aziz Hussin revealed that there are nine trends related to Education 4.0. First, learning can be done anytime, anywhere. Second, learning will be individual for each student. Third, students have choices in determining how they want to learn. Fourth, students will be exposed to more project-based learning. Fifth, students will be exposed to direct learning through field experiences such as internships, mentoring projects and collaborative projects. Sixth, students will be exposed to data interpretation in which they are asked to apply their theoretical knowledge to numbers and use their reasoning skills to make inferences based on the logic and trends of a given data set. Seventh, students will be assessed differently, and conventional platforms for assessing students may be irrelevant or inadequate. Students' factual knowledge can be assessed during the learning process, while the application of knowledge can be tested when they are working on their projects in the field. Eighth, students' opinions will be considered in designing and updating the curriculum. Finally, students will become more independent in their learning, forcing teachers to take on new roles as facilitators who will guide students through their learning process.

Islamic education has advantages and virtues because its basis and purpose depart from Allah's revelations (al-Qur'an and Sunnah). In general, Muslims understand the substance of Islamic education as a conscious effort to form a superior human person in accordance with the values of Islamic teachings. A superior human being is a person whose full potential can be developed optimally, including his physical, senses, intuition and spiritual. The main components of Islamic education, according to experts, are summarized in three elements, namely al-tarbiyah (guiding, protecting), al-ta'lim (teaching, developing) and al-ta 'dib (educating morals). While the compulsory curriculum material is summarized in the integralization of three, the basic components of Islamic teachings are faith, Islam and Ihsan (akidah, shari'ah and morals-tasawuf).

Islamic education is still left behind with the West due to several things, including: first, the orientation of its education must be clarified towards the goal which should be by Islamic orientation. Islamic education is only concerned with the transfer of religious knowledge. Second, the practice of Islamic education still maintains the old heritage, so that the knowledge learned is classical science and modern science is not touched. Third, Muslims are still busy being lulled by the romance of the past. The greatness of the Muslims from the past to the present day still affects the mindset of Muslims. They are still proud of the glory of the past but do not realize that this pride is what causes them to be left behind.

Therefore, to welcome the era of the industrial revolution 4.0, the concept of Islamic education and a very basic role in empowering Muslims is needed. In this perspective, Islamic educational institutions are expected to be able to improve themselves, so that they are not only able to become a medium for transmitting culture, knowledge and expertise, but also as potential and cultural interactions, namely how Islamic educational institutions can develop 
the potential of children given by Allah. since birth in the context of preparing students to live their lives.

To welcome Islamic Education 4.0, inevitably all of the latent problems above must be able to find solutions. If not, then it will be difficult to create Islamic education that is contextual to the times. Therefore, there is a need for reform and renewal of all aspects of Islamic education. According to Rhenald Kasali, there are three steps that Islamic education must take in this era of 4.0, namely disruptive mindset, self-driving, and reshape or create. Disruptive mindset. Mindset is how humans think which is determined by the settings we make before thinking and acting. Islamic education today is in a fast-paced digital age, high mobility, access to information is everyone's primary need. Everything that is needed must be immediately available if the access requires a relatively long time; the community will leave it and switch to other services that are faster and have easy access.

Self-Driving. Organizations that are agile and dynamic in adapting to navigate the ocean of disruption are organizations that have human resources with the mentality of good drivers, not passengers. Human resources with good driver mentality will be willing to open themselves up, quickly and accurately read the situation, have integrity, are agile in acting, be aware of all bad possibilities, and can work effectively, which gives birth to the scientific dichotomy that has been inherited by the Muslim community since the decline of Islam (twelfth century).

Reshape or Create. There is an analogy of thought that is popular among Muslims which is still adhered to, namely maintaining the good old and taking the new which is better. However, in the era of the industrial revolution 4.0, there needs to be a lot of changes starting from the level of management and professionalism of human resources that require increased competence and capacity. It can be done in various ways, including through training, seminars, workshops, study scholarships, and so on. Another way to respond to the era of the industrial revolution 4.0 can be done by creating. Create is to create something new that was not there before. It can be said that it replaces the old system which has expired. Outdated systems are replaced with new systems, for example, developing a new digital-based service system. So that members of Islamic education institutions can freely access all needs related to education and administrative services. Another example, developing contemporary learning models by fully utilizing digital technology, such as e-learning, blended learning, and so on.

Facing disruption means the readiness for the innovation. It also demands winning solution for the problems occured. Franken says that one of the problems occured is the lack of the skill. Therefore, the Islamic education system should transform to face the challenge of the disruption era. Competencies should be entailed to develop their skills. However, the most important thing is mantaining their spiritual and behavioral aspect. By having the support from the parents, familiy environment, and teachers, which are then applied in life will create golden Muslim generations. It will prevent from the neagtive impacts and moral damage that have plauged in this disruption time.

Besides, Abdullah argues that old patterns of thinking, traditionalist-conventionalist, seems to be status quo, antagonist, black and white, exclusive, absolute, dogmatic, truth claims, closed and stiff. These should be turned into a revisionist one. It should be more conducive to spread the seeds of meaningful participation, uptodate information, open minded perspectives.

\section{Conclusion}

The disruptive era presents various changes that are sometimes difficult for society to follow. Therefore, Islamic education must be able to position itself as an educational 
institution that is ready to produce a golden generation of noble character. However, this is not easy. It requires a struggle for existence in competing with other educational institutions. It demands to be open and willing to accept all changes in this era. Consequently, they need to innovate to be able to compete with others.

The transformation of Islamic education is carried out to meet the needs of society in the era of the Industrial Revolution 4.0. It is because the market requires competent human resources. Some developments need to be carried out in several aspects, including mastery of foreign languages, entrepreneurship, ICT (Information and Communication Technology), as well as other competencies and skills. However, the important thing that must be held is that Islamic boarding school have to orientate the quality improvement of their students towards mastery of the religious sciences. The era of the Industrial Revolution 4.0 is just one of the many challenges that Islamic boarding school must respond to without leaving their identity.

\section{References}

[1] Abdullah, Muhammad Amin. "Islamic Studies in Higher Education in Indonesia: Challenges, Impact and Prospects for the World Community." Al-Jami'ah: Journal of Islamic Studies 55, no. 2 (December 15, 2017): 391-426. https://doi.org/10.14421/ajis.2017.552.391-426.

[2] Abitolkha, Amir Maliki, Ahmad Nur Ismail, and Yazid Hady. "Contextualization of Islamic Education Curriculum in Junior High Schools." TARBIYA: Journal of Education in Muslim Society 7, no. 1 (September 23, 2020): 48-66. https://doi.org/10.15408/tjems.v7i1.13843.

[3] Daulay, Haidar Putra. Sejarah Pertumbuhan Dan Pembaruan Pendidikan Islam Di Indonesia. Jakarta: Kencana Prenada Media, 2012.

[4] Franken, Leni. "Islamic Education in Belgium: Past, Present, and Future." Religious Education 112, no. 5 (2017): 491-503.

[5] Hasbullah. Sejarah Pendidikan Islam Di Indonesia: Lintasan Pertumbuhan Dan Perkembangan. Jakarta: PT Raja Grafindo Persada, 1996.

[6] Hielmy, Irfan. Wancana Islam. Ciamis: Pusat Informasi Pesantren, 2000.

[7] Hussin, Anealka Aziz. "Education 4.0 Made Simple: Ideas for Teaching." International Journal of Education and Literacy Studies 6, no. 3 (2018): 92-98.

[8] Kasali, Rhenald. "Disruption," 2018.

[9] Khatibah, Khatibah. "Penelitian Kepustakaan." Iqra': Jurnal Perpustakaan Dan Informasi 5, no. 01 (2011): 36-39.

[10] Ma'arif, Syamsul. Revitalisasi Pendidikan Islam. Yogyakarta: Graha Ilmu, 2007.

[11] Mohamed, Sumaya, and Shadiya Baqutayan. "Toward Social Change in Islam." International Journal of Basic \& Applied Sciences 11, no. 2 (2011): 23-33.

[12] Nahrawi, Amiruddin. Pembaharuan Pendidikan Pesantren. Gama Media, 2008.

[13] Nata, Abuddin. "Metodologi Studi Islam Edisi Revisi 12." Jakarta: Raja Grafindo Persada, 2008.

[14] Nata, Abudin, and Sejarah Pertumbuhan Dan Perkembangan Lembaga-Lembaga. Pendidikan Islam Di Indonesia. Jakarta: PT Prenada Media, 2008.

[15] Nizar, H. Samsul. Sejarah Sosial Dan Dinamika Intelektual Pendidikan Islam Di Nusantara. Kencana, 2013.

[16] "Peraturan Menag No. 13 Tahun 2014 Tentang Pendidikan Keagamaan Islam," n.d. Accessed August 31, 2020. 
[17] Steenbrink, Karel A. Pesantren Madrasah Sekolah. Jakarta: LP3ES, 1986.

[18] Sugiyono, Prof. Memahami Penelitian Kualitatif. Bandung: Alfabeta, 2005.

[19] Tafsir, Ahmad, Ahmad Supardi, Hasan Basri, Mahmud Mahmud, Opik Taufik Kurahman, Pupuh Fathurrahman, Tedi Priatna, Supriatna Supriatna, Uus Ruswandi, and Yaya Suryana. Cakrawala Pemikiran Pendidikan Islam. Vol. 1. Mimbar Pustaka: Media Tranformasi Pengetahuan, 2004.

[20] Wahab, Rochidin. Sejarah Pendidikan Islam Di Indonesia. Bandung: Alfabeta, 2004. 